\title{
CHEMOSPHERE
}

\section{Ozonation of activated carbon and its effects on the adsorption of VOCs exemplified by methylethylketone and benzene}

\author{
Hung-Lung Chiang a , P.C. Chiang ${ }^{b}$, C.P. Huang ${ }^{\mathrm{c}, *}$ \\ a Department of Environmental Engineering, Fooyin Institute Technology, Kaoshiung Hsien 831, Taiwan, ROC \\ ${ }^{\mathrm{b}}$ Graduate Institute of Environmental Engineering, National Taiwan University, No. 71, Chou-Shan Road, Taipei, Taiwan, ROC \\ ${ }^{\mathrm{c}}$ Department of Civil and Environmental Engineering, University of Delaware, Newark, DE 19716, USA
}

Received 17 April 2000; received in revised form 6 July 2001; accepted 13 August 2001

\begin{abstract}
Ozonation can modify the surface property of an activated carbon such as specific surface area, pore volume, and functional group. Results indicate that ozonation can increase the specific surface area of an activated carbon from $783 \pm 51$ to $851 \pm 25 \mathrm{~m}^{2} / \mathrm{g}$ due in part to increasing micropores (those below $15 \AA$ ). However, there is no change in macropore and mesopore upon ozonation. The amount of oxygen functional group (OFG) increases from $197 \pm 4$ to $240 \pm 4 \mu \mathrm{eq} / \mathrm{g}$, mostly in hydroxyl and carboxyl groups upon ozone treatment. These oxygen-containing functional groups are stable in the temperature range $30-250{ }^{\circ} \mathrm{C}$, but begin to decompose when temperature increases beyond 300 and $350{ }^{\circ} \mathrm{C}$. When the temperature reaches $1200{ }^{\circ} \mathrm{C}$, all OFGs virtually disappear. The effect of ozone treatment on the adsorption of volatile organic carbon (VOC) was exemplified by methylethylketone (MEK) and benzene. The adsorption density of MEK and benzene by ozone treated activated carbon $\left(\mathrm{AC}\left(\mathrm{O}_{3}\right)\right)$ are greater than that by the untreated (AC), with MEK being more adsorbable than benzene. Results of factorial analysis indicate that physical characteristics, namely, micropore, BET surface area, pore diameter (PD), micropore volume (MV) play an important role on benzene and MEK adsorption. (c) 2002 Elsevier Science Ltd. All rights reserved.
\end{abstract}

Keywords: Activated carbon; VOCs; Ozonation; Physical properties

\section{Introduction}

When activated carbon is exposed to the atmosphere and allowed to react with oxygen, its surface property changes (Mattson and Mark, 1971). Ozone oxidation of activated carbon can modify the surface oxygen functional group (OFG), thereby enhancing its polarity and subsequently affect the adsorption capacity for organic contaminants.

Many factors can affect the adsorption capacity of an activated carbon. These include specific surface area, pore-size distribution, pore volume, and surface func-

\footnotetext{
*Corresponding author. Tel.: +1-302-831-8428; fax: +1-302831-3640.

E-mail address: huang@mail.ce.udel.edu (C.P. Huang).
}

tional group. Generally, the adsorption capacity increases with specific surface area, due to the availability of adsorption site (Ruthven, 1984). Pore size and poresize distribution are closely related to the composition of the activated carbon, the degree of activation and the frequency of regeneration. Urano et al. (1982) indicated that the adsorption capacity is proportional to the cumulative micropore volume (MV) (micropore size less than $3.2 \mathrm{~nm}$ ). Stern (1977) found that the average molecular size of air pollutant is between 40 and $85 \mathrm{~nm}$ and suggested that micropores can play an important role in the adsorption of air pollutants.

The non-polar nature of virgin activated carbon displays a high affinity toward non-polar organic compounds. Kinoshita (1988) reported that the surface functional group of activated carbon consists of oxygen, hydrogen, nitrogen, sulfur, halogen, and other elements. 
These surface elements are responsible for the adsorption of air contaminants. At room temperature, activated carbon reacts readily with oxygen to form functional groups of oxygen complexes on the surface Walker and Janov, 1968. The surface functional groups can affect the physico-chemical characteristics (such as dampness, catalytic effect, and electrical properties) of the activated carbon.

Boehm (1966) and Puri (1970) classified the functional group into acid, base, and neutral type. The acidic group includes $-\mathrm{COOH},-\mathrm{OH},-\mathrm{C}=\mathrm{O}$, and $-\mathrm{COO}-$. In order to attain a high concentration of OFG, oxidants are used as activation agents during the manufacturing of activated carbon (Mattson and Mark, 1971). The following chemicals, mostly gases, are commonly used as activation agents: $\mathrm{O}_{2}, \mathrm{NO}, \mathrm{CO}_{2}$, and $\mathrm{H}_{2} \mathrm{O}$ (Laine et al., 1963; Hart et al., 1967; Lussow et al., 1967; Walker and Janov, 1968; Turkdogan and Vinter, 1969, 1970; Bansal et al., 1970a,b; Phillips et al., 1970; Kinoshita, 1988). Other strong oxidants such as $\mathrm{KMnO}_{4}, \mathrm{HNO}_{3}$, and $\mathrm{KClO}_{4}$ can also be used in liquid-phase activation processes (Puri and Bansal, 1964; Norwitr and Galan, 1967; Matsumura et al., 1976; Hagiwan et al., 1978; Hahn et al., 1981).

Zarifyanz et al. (1967) have shown that oxygen reacts with graphite at temperatures below $-40{ }^{\circ} \mathrm{C}$ to form surface oxides, which can be readily removed as $\mathrm{CO}$ or $\mathrm{CO}_{2}$ at temperatures above $200{ }^{\circ} \mathrm{C}$. In general, carboxylic and lactone groups begin to decompose at about $250{ }^{\circ} \mathrm{C}$, and the phenol and quinone groups decompose almost completely between 500 and $900{ }^{\circ} \mathrm{C}$. At $900{ }^{\circ} \mathrm{C}$, the hydroxyl group decreases drastically and the other oxygen-containing surface functional groups are completely eliminated (Kinoshita, 1988).

Pretreatment of activated carbon increases the surface area and the concentration of surface functional group, which in turn can enhance the adsorption capacity. Two mechanisms are involved in the oxidation of carbon black by ozone: (i) direct oxidation of elemental carbon to $\mathrm{CO}_{2}$ and (ii) oxidation of elemental carbon to intermediates that are soluble in alkaline solutions and are subsequently oxidized to $\mathrm{CO}_{2}$. Deitz and Bitner $(1972,1973)$ showed that a large amount of ozone was adsorbed on the graphite surface, $\mathrm{C}$, with the formation of ozonated surface complexes such as $\mathrm{CO}_{3}$ and $\mathrm{CO}$ :

$$
\begin{aligned}
& \underline{\mathrm{C}}+\mathrm{O}_{3}=\underline{\mathrm{CO}}_{3} \\
& \mathrm{C}+\mathrm{O}_{3}=\underline{\mathrm{CO}}+\mathrm{O}_{2}
\end{aligned}
$$

It has been reported that gas-phase oxidation by ozone takes place at the edge and terrace of the graphite structure and the basal plane, and subsequently pits the surface. Donnet et al. (1970a,b, 1982) conducted experiments on the ozonation of activated carbon and reported that at a dosage of $13 \mathrm{mg} \mathrm{O}_{3} / \mathrm{l}, 65 \%$ of the activated carbon surface were oxidized to $\mathrm{CO}_{2}$. The degree of oxidation, however, was independent of temperature and $\mathrm{O}_{3}$ concentration. While literature reports appear to suggest that $\mathrm{O}_{3}$ treatment can alter the surface functional group of an activated carbon, very little quantitative information is available on the possible modification of the physical property of the treated activated carbon. The objective of this research was to examine the change of physical-chemical properties of an activated carbon by ozonation and its effects on the adsorption of volatile organic compounds (VOCs) exemplified by methylethylketone (MEK) and benzene. Factorial analysis technique was used to determine the important parameters controlling the VOC adsorption.

\section{Experimental methods}

An activated carbon, KOWA-COSMOS $(8 \times 30$ mesh), was selected for this study. The activated carbon was treated continuously by ozone for $30 \mathrm{~min}$ at a concentration of $40 \mathrm{mg} / \mathrm{l}$ and a flow rate of $2.5 \mathrm{1} / \mathrm{min}$ (or a mass rate of $100 \mathrm{mg} / \mathrm{min}$ ). The activated carbon was then stored in an oven at $105{ }^{\circ} \mathrm{C}$ and dried for $48 \mathrm{~h}$. The physical characteristics of activated carbon, including specific surface area, total pore volume, MV, pore-size distribution, and pore diameter were measured. Most of the above properties can be measured by $\mathrm{N}_{2}(\mathrm{~g})$ adsorption at $77 \mathrm{~K}$ using an ASAP 2000 micropore analyzer. Micropore characteristics diameter was measured with $\mathrm{Ar}$ (g) adsorption also using an ASAP $2000 \mathrm{mi}-$ cropore analyzer at $77 \mathrm{~K}$ in liquid $\mathrm{N}_{2}$.

The specific surface area was calculated by the BET method (Brunauer et al., 1938). The micropore surface area was determined by subtracting the external surface area from the BET surface area.

The total pore volume was determined by the BJH method (Barrett et al., 1951). The MV was calculated by the $t$-plot and the Harkins-Jura method (Harkins and Jura, 1944; Lippens and de Boer, 1965).

Surface elemental composition, namely, carbon, nitrogen, hydrogen and oxygen was analyzed with a Heraeus $\mathrm{CHNO}$ rapid element analyzer. A total of five samples were analyzed in duplicate. Acetanilide was used as the standard. Sulfur and chlorine were analyzed with Tacussel Coulomax 78 using sulfanilic acid and 1-chloro-2,4-dintrobenzene standards. Other elements such as $\mathrm{Ca}, \mathrm{S}, \mathrm{Fe}, \mathrm{K}, \mathrm{Al}, \mathrm{Mg}, \mathrm{Na}, \mathrm{Cr}$ were analyzed with ICP-AES against a standard reference, NBS SRM-1648.

OFG was analyzed by alkalimetric titration according to procedures of Boehm (1966) and Fabish and Schleifer (1984). Activated carbon sample (ca. $5 \mathrm{~g}$ ) was first dried in a vacuum oven at $10^{-2}$ to $10^{-3} \mathrm{~mm} \mathrm{Hg}$, and $105^{\circ} \mathrm{C}$ for $24 \mathrm{~h}$ before titration. The titration began by adding $25 \mathrm{ml}$ of $\mathrm{NaOH}(0.1 \mathrm{~N})$ solution to a series of test tubes containing a given amount of the activated carbon. The sample was mixed over a vibrator at 
$100 \mathrm{rpm}$ and $25^{\circ} \mathrm{C}$ for $24 \mathrm{~h}$. A given amount of the supernatant $(5 \mathrm{ml})$ was then drawn from the test tubes and back-titrated with $\mathrm{HCl}(0.1 \mathrm{~N})$ solution. The concentrations of various functional groups were calculated by the net amount of alkali consumed.

The surface OFGs are generally stable under vacuum below their formation temperatures (Puri and Bansal, 1964; Bansal et al., 1977) and definitely stable at temperatures below $200{ }^{\circ} \mathrm{C}$. The thermal desorption processes, carried out in vacuum at a linearly programmed heating rate, typically $2.5^{\circ} \mathrm{C} / \mathrm{min}$, followed those of Puri and Bansal (1964), and Bansal et al. (1977). The surface OFGs of activated carbon after pyrolysis in vacuum were analyzed by Boehm's method.

Procedures for kinetic adsorption experiments and related adsorption conditions were as the following. Placed $50 \mathrm{mg}$ of activated carbon in an electrical-balance that was already connected to a data acquisition system. The influent relative vapor pressure of benzene was set at the range from 0.005 to $0.016 \mathrm{~atm}$ and that of MEK was from 0.003 to $0.010 \mathrm{~atm}$. The inflow rate of benzene and MEK vapor was set at $2.0 \mathrm{1} / \mathrm{min}$ and the adsorption temperature was maintained at $30 \pm 0.1{ }^{\circ} \mathrm{C}$. The kinetic adsorption runs were repeated four times for all experimental concentrations.

Factor analysis was conducted. Factor analysis involves several steps. First, the correlation or covariance matrix is computed from the usual case-by-variables data file. Second, the factor loadings are estimated. Third, the factors are rotated to make the loadings more interpretable, that is, rotation methods make the loadings for each factor either large or small, not in-between.

\section{Results and discussion}

\subsection{Surface physical characteristics}

For each adsorbent, five separate samples were taken for the analysis of physical characteristics. For quality assurance, three of the five samples were analyzed in duplicate. Surface physical characteristics analyzed were BET specific surface area, micropore area (MA), MV and pore diameter (PD). Table 1 shows the results of physical characteristics of activated carbons studied.
The BET specific surface area of the activated carbon (AC) and the oxidized activated carbon $\left(\mathrm{AC}\left(\mathrm{O}_{3}\right)\right)$ are $783 \pm 51$ and $851 \pm 25 \mathrm{~m}^{2} / \mathrm{g}$, respectively. The specific surface area of $\mathrm{AC}\left(\mathrm{O}_{3}\right)$ increases by $8.7 \%$ over that of the AC. Apparently ozonation alters the pore size and its distribution which in turn increases the specific surface area.

The MA is $677 \pm 41$ and $727 \pm 16 \mathrm{~m}^{2} / \mathrm{g}$ for $\mathrm{AC}$ and $\mathrm{AC}\left(\mathrm{O}_{3}\right)$, respectively. Results indicate that oxidation increases mainly the micropore surface area as MA contributes $74 \%$ of the specific surface area increase.

Upon oxidation, the MV also increases from $0.320 \pm 0.002$ to $0.344 \pm 0.009 \mathrm{~cm}^{3} / \mathrm{g}$ (an increase of $7.5 \%)$ and the PD slightly rises from $14.60 \pm 0.03$ to $14.67 \pm 0.03 \AA$ (an insignificant increase of $0.5 \%$ ). There is almost no difference in PD between $\mathrm{AC}$ and $\mathrm{AC}\left(\mathrm{O}_{3}\right)$.

There is no significant difference in macropore and mesopore volume distribution between $\mathrm{AC}$ and $\mathrm{AC}\left(\mathrm{O}_{3}\right)$ (Figs. 1 and 2). As seen in Figs. 1 and 2, the variation of pore volume distribution curves obtained from desorption runs is greater than that from adsorption runs. This can be attributed in part to the presence of a hysteresis during nitrogen desorption caused by the micropore structure. The pore volume for pore size in the range between 6 and $7 \AA$ of $\mathrm{AC}$ is greater than that of $\mathrm{AC}\left(\mathrm{O}_{3}\right)$. The pore volume for pore size under $6 \AA$ of $\mathrm{AC}\left(\mathrm{O}_{3}\right)$ is greater than that of AC (Fig. 3).

\subsection{Chemical characteristics}

Table 2 gives the concentration of major surface elements of $\mathrm{AC}$ and $\mathrm{AC}\left(\mathrm{O}_{3}\right)$. The concentration of nitrogen, carbon, hydrogen, and oxygen of AC are $0.22 \%$, $87.13 \%, 1.70 \%$, and $10.95 \%$, respectively. The concentration of $\mathrm{N}, \mathrm{C}, \mathrm{H}$, and $\mathrm{O}$ of $\mathrm{AC}\left(\mathrm{O}_{3}\right)$ are $0.20 \%, 86.84 \%$, $1.61 \%$, and $11.35 \%$, respectively. Results indicate that the concentration of oxygen slightly increases by $0.29 \%$, whereas hydrogen decreases by $0.09 \%$ upon ozone treatment.

Tables 3 and 4 show the changes in surface functional groups of the activated carbon due to ozonation. As expected, there is a substantial increase in oxygen surface functional groups by ozone oxidation. The functional group $-\mathrm{OH}$ of $\mathrm{AC}$ is $117 \pm 7 \mu \mathrm{eq} / \mathrm{g}$ and upon ozonation it increases by $23 \%$ to $144 \pm 5 \mu \mathrm{eq} / \mathrm{g}$. The

Table 1

Physico-chemical characteristics of activated carbon as affected by ozone oxidation ${ }^{\mathrm{a}}$

\begin{tabular}{llllll}
\hline Items & BET $\left(\mathrm{m}^{2} / \mathrm{g}\right)$ & $\mathrm{MA}\left(\mathrm{m}^{2} / \mathrm{g}\right)$ & $\mathrm{PD}(\AA)$ & $\begin{array}{l}\text { Total pore } \\
\text { volume }\left(\mathrm{cm}^{3} / \mathrm{g}\right)\end{array}$ & $\mathrm{MV}\left(\mathrm{cm}^{3} / \mathrm{g}\right)$ \\
\hline $\mathrm{AC}$ & $783 \pm 51$ & $677 \pm 41$ & $14.60 \pm 0.03$ & $0.367 \pm 0.006$ & $0.320 \pm 0.002$ \\
$\mathrm{AC}\left(\mathrm{O}_{3}\right)$ & $851 \pm 25$ & $727 \pm 16$ & $14.67 \pm 0.03$ & $0.400 \pm 0.005$ & $0.344 \pm 0.009$ \\
Percent variation $^{\mathrm{b}}$ & $8.7 \%$ & $7.4 \%$ & $0.5 \%$ & $9.0 \%$ & $7.5 \%$ \\
\hline
\end{tabular}

${ }^{\text {a }}$ Sample number is 5 and the measurement of PD is less than $2000 \AA$.

${ }^{\mathrm{b}}$ Percent of variation $=\left(\mathrm{AC}\left(\mathrm{O}_{3}\right)-\mathrm{AC}\right) / \mathrm{AC} \times 100 \%$. 


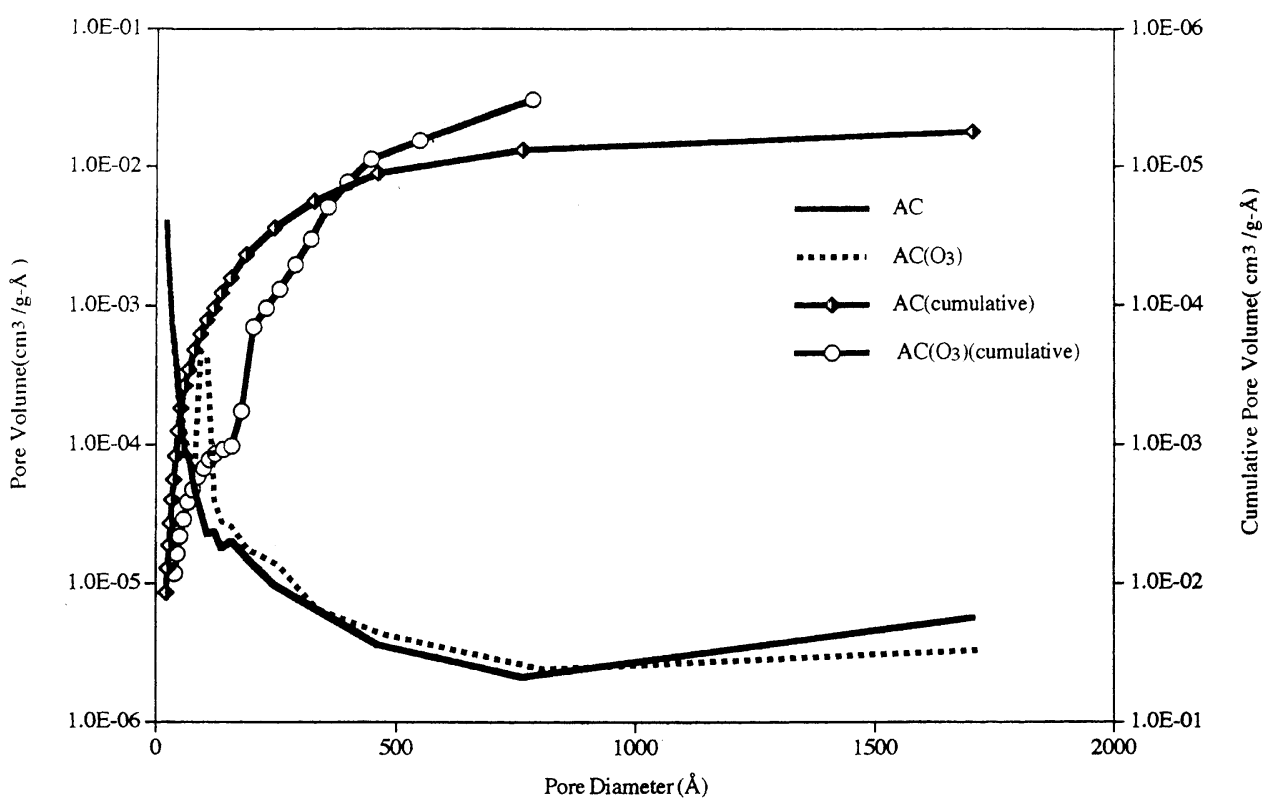

Fig. 1. Macropore and mesopore volume distribution of $\mathrm{AC}$ and $\mathrm{AC}\left(\mathrm{O}_{3}\right)$ under adsorption process.

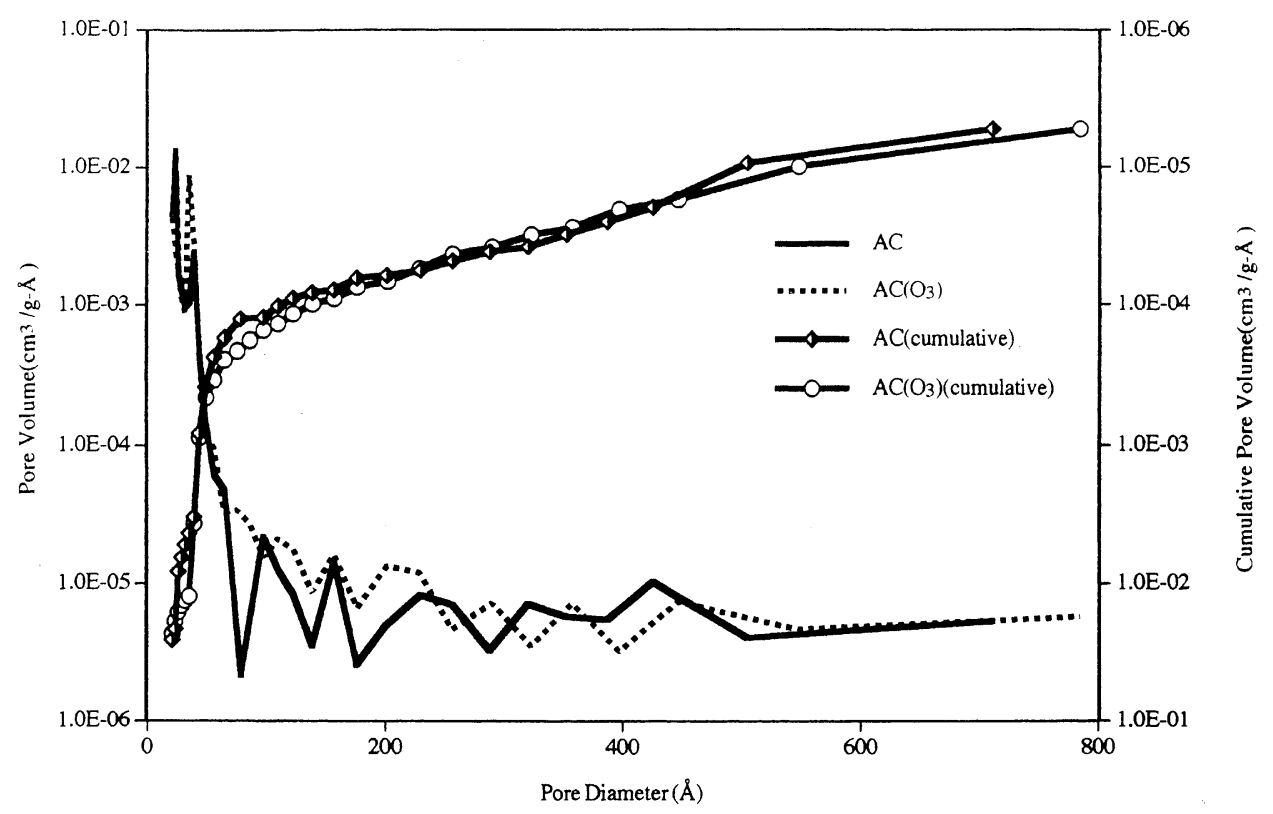

Fig. 2. Macropore and mesopore volume distribution of $\mathrm{AC}$ and $\mathrm{AC}\left(\mathrm{O}_{3}\right)$ under desorption process.

$-\mathrm{C}=\mathrm{O}$ functional group increases from $46 \pm 6$ to $52 \pm$ $14 \mu \mathrm{eq} / \mathrm{g}$ and the $-\mathrm{COOH}$ functional group increases from $34 \pm 4$ to $44 \pm 10 \mu \mathrm{eq} / \mathrm{g}$ upon ozone treatment. In terms of surface area, the OFGs increase by $12 \%$ due to ozone treatment.

The sum of the OFGs increases from $197 \pm 4$ to $240 \pm 4 \mu \mathrm{eq} / \mathrm{g}$ by ozonation. This is an overall increase of $22 \%$. The increase in $-\mathrm{OH},-\mathrm{C}=\mathrm{O}$, and $-\mathrm{COOH}$ functional group is $23 \%, 13 \%$, and $29 \%$, respectively.

Fig. 4 shows the desorption of OFGs as a function of temperature between 30 and $1200{ }^{\circ} \mathrm{C}$. Results indicate that the OFGs are stable in the less than $250-300{ }^{\circ} \mathrm{C}$ range. The amount of OFG decreases drastically in the $250-300{ }^{\circ} \mathrm{C}$ range. The amount of OFG desorption be- 


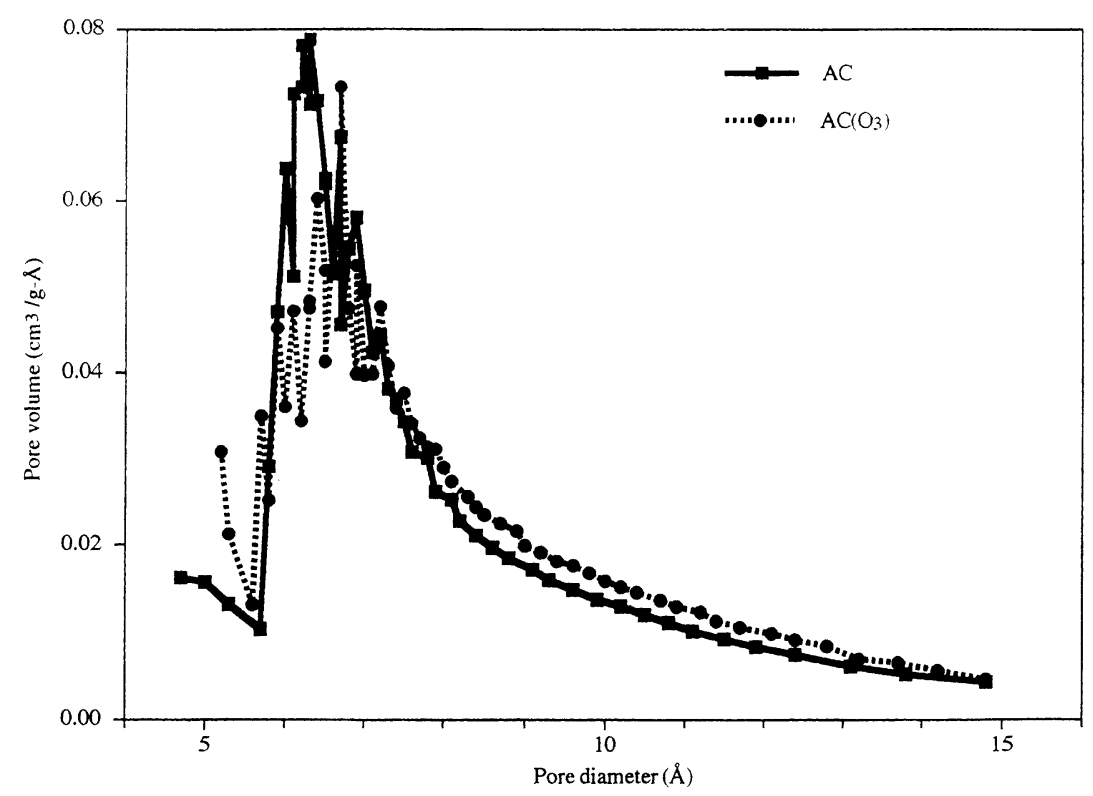

Fig. 3. MV distribution of $\mathrm{AC}$ and $\mathrm{AC}\left(\mathrm{O}_{3}\right)$.

Table 2

Major surface elements of activated carbon as affected by ozone oxidation ${ }^{\text {a }}$

\begin{tabular}{lllllll}
\hline $\begin{array}{l}\text { Activated } \\
\text { carbon }(\%)\end{array}$ & $\mathrm{N}$ & $\mathrm{C}$ & $\mathrm{H}$ & $\mathrm{O}$ & $\mathrm{S}$ & $\mathrm{Cl}$ \\
\hline $\mathrm{AC}$ & $0.22(0.22)^{\mathrm{b}}$ & $86.52(87.13)$ & $1.69(1.70)$ & $10.87(10.95)$ & $\mathrm{ND}^{\mathrm{c}}$ & $\mathrm{ND}^{\mathrm{N}}$ \\
$\mathrm{AC}\left(\mathrm{O}_{3}\right)$ & $0.20(0.20)$ & $87.21(86.84)$ & $1.62(1.61)$ & $11.40(11.35)$ & $\mathrm{ND}$ & $\mathrm{ND}$ \\
\hline
\end{tabular}

${ }^{\text {a }}$ Triplicate samples.

${ }^{\mathrm{b}}$ Figures in parentheses designated correction data that based on the sum of the concentration of N, C, H, O, S and $\mathrm{Cl}$ which is equal to $100 \%$.

${ }^{\mathrm{c}} \mathrm{ND}$ : detection value $<0.01 \%$.

Table 3

OFGs concentration of $\mathrm{AC}$ and $\mathrm{AC}\left(\mathrm{O}_{3}\right)^{\mathrm{a}}$

\begin{tabular}{|c|c|c|c|c|c|}
\hline Activated carbon & & $\mathrm{OH}$ & $\mathrm{CO}$ & $\mathrm{COOH}$ & OFG \\
\hline $\mathrm{AC}$ & $\mu \mathrm{eq} / \mathrm{g}$ & $117 \pm 7$ & $46 \pm 6$ & $34 \pm 4$ & $197 \pm 4$ \\
\hline \multirow{3}{*}{$\mathrm{AC}\left(\mathrm{O}_{3}\right)$} & $\mu \mathrm{eq} / 100 \mathrm{~m}^{2}$ & $15 \pm 9$ & $6 \pm 0.8$ & $4 \pm 0.5$ & $25 \pm 0.5$ \\
\hline & $\mu \mathrm{eq} / \mathrm{g}$ & $114 \pm 5$ & $52 \pm 14$ & $44 \pm 10$ & $240 \pm 4$ \\
\hline & $\mu \mathrm{eq} / 100 \mathrm{~m}^{2}$ & $17 \pm 0.6$ & $6 \pm 1.6$ & $5 \pm 1.2$ & $28 \pm 0.5$ \\
\hline Percent & $\mu \mathrm{eq} / \mathrm{g}$ & 23 & 13 & 29 & 22 \\
\hline variation $^{\mathrm{b}}(\%)$ & $\mu \mathrm{eq} / 100 \mathrm{~m}^{2}$ & 13 & 0 & 12 & 12 \\
\hline
\end{tabular}

${ }^{\text {a }}$ Sample number is 5 .

${ }^{\mathrm{b}}$ Percent of variation $=\left(\mathrm{AC}\left(\mathrm{O}_{3}\right)-\mathrm{AC}\right) / \mathrm{AC} \times 100 \%$.

comes insignificant in the $700-1000{ }^{\circ} \mathrm{C}$ range. Generally, the decomposition of carboxylic and lactone groups begins at about $250{ }^{\circ} \mathrm{C}$. Phenolic and quinone groups are removed between 450 and $900{ }^{\circ} \mathrm{C}$. When the temperature exceeds $900{ }^{\circ} \mathrm{C}$, all OFGs are almost completely destroyed.
Fig. 5 shows the rate of MEK and benzene adsorption onto ozone-treated and untreated activated carbons as a function of relative pressure, $p / p_{0}$. The adsorption rate (AR) of benzene increases from 32 to $102 \mathrm{mg} / \mathrm{g}$ h for $\mathrm{AC}$ and from 20 to $114 \mathrm{mg} / \mathrm{g} \mathrm{h}$ for $\mathrm{AC}\left(\mathrm{O}_{3}\right)$ when the influent relative vapor pressure increases from 0.005 to 
Table 4

The results of factorial analysis (rotated factor pattern)

\begin{tabular}{|c|c|c|c|}
\hline Items & Group I & Group II & $\begin{array}{l}\text { Group } \\
\text { III }\end{array}$ \\
\hline \multicolumn{4}{|c|}{ (a) Benzene adsorption } \\
\hline MA & $0.97^{\mathrm{a}}$ & 0.26 & \\
\hline BET & 0.95 & 0.31 & \\
\hline PD & 0.86 & 0.45 & \\
\hline MV & 0.72 & 0.62 & \\
\hline OFG & 0.58 & 0.80 & \\
\hline $\mathrm{AR}$ & 0.66 & 0.71 & \\
\hline$Q$ & 0.19 & -0.98 & \\
\hline Variance & 3.89 & 2.85 & \\
\hline $\begin{array}{l}\text { Percent of } \\
\text { total variance }\end{array}$ & 55.52 & 40.73 & \\
\hline \multicolumn{4}{|c|}{ (b) $M E K$ adsorption } \\
\hline MA & 0.93 & 0.03 & 0.27 \\
\hline BET & 0.91 & 0.06 & 0.61 \\
\hline PD & 0.80 & 0.16 & 0.61 \\
\hline MV & 0.66 & 0.34 & 0.67 \\
\hline OFG & 0.30 & 0.60 & 0.54 \\
\hline AR & 0.55 & -0.05 & 0.83 \\
\hline$Q$ & -0.01 & -0.96 & -0.01 \\
\hline Variance & 3.40 & 1.41 & 2.85 \\
\hline $\begin{array}{l}\text { Percent of } \\
\text { total variance }\end{array}$ & 55.52 & 40.73 & 40.73 \\
\hline
\end{tabular}

${ }^{\mathrm{a}}$ Factor loading.

0.015. In the case of MEK, when the influent relative vapor pressure increases from 0.003 to 0.010 , the AR increases from 18 to $102 \mathrm{mg} / \mathrm{g}$ h for $\mathrm{AC}$ and from 30 to $106 \mathrm{mg} / \mathrm{g}$ h for $\mathrm{AC}\left(\mathrm{O}_{3}\right)$. Moreover, the $\mathrm{AR}$ by $\mathrm{AC}\left(\mathrm{O}_{3}\right)$ is generally greater than that by $\mathrm{AC}$. This can be attributed to the change of the physical characteristics. It is noted that the BET surface area and the MV of $\mathrm{AC}\left(\mathrm{O}_{3}\right)$ are greater than those of $\mathrm{AC}$. The pore diameter of $\mathrm{AC}\left(\mathrm{O}_{3}\right)$ is narrower than that of $\mathrm{AC}$. Moreover, the average micropore size of $\mathrm{AC}\left(\mathrm{O}_{3}\right)$ is smaller than that of AC. As predicted by the Kelvin equation (Adamson, 1982), the smaller the PD, the lower the relative vapor pressure during capillary condensation. As a result, the $\mathrm{AR}$ of $\mathrm{AC}\left(\mathrm{O}_{3}\right)$ will be greater than that of $\mathrm{AC}$ under otherwise identical experimental conditions. Results also indicated that the AR of MEK is greater than that of benzene over the relative vapor pressure range studied. This is attributed in part to the adsorption energy of benzene $(34.4 \mathrm{~kJ} / \mathrm{mol})$ higher than MEK $(23.5 \mathrm{~kJ} / \mathrm{mol})$ (Chiang et al., 2002).

Fig. 6 shows the adsorption of MEK and benzene as a function of partial pressure. The increase in influent relative vapor pressure of benzene from 0.005 to 0.016 resulted an increase in adsorption density from 208 to $226 \mathrm{mg} / \mathrm{g}$ on $\mathrm{AC}$ and from 188 to $210 \mathrm{mg} / \mathrm{g}$ on $\mathrm{AC}\left(\mathrm{O}_{3}\right)$. The benzene adsorption capacity of $\mathrm{AC}$ is greater than that of $\mathrm{AC}\left(\mathrm{O}_{3}\right)$ at various benzene concentrations. This is expected as the surface of $\mathrm{AC}\left(\mathrm{O}_{3}\right)$ is more polar than that of $\mathrm{AC}$ and benzene is a nonpolar adsorbate, the benzene-specific adsorption sites will be less on $\mathrm{AC}\left(\mathrm{O}_{3}\right)$ than AC.

The adsorption capacity of MEK increases from 166 to $214 \mathrm{mg} / \mathrm{g}$ by $\mathrm{AC}$ and from 192 to $214 \mathrm{mg} / \mathrm{g}$ by $\mathrm{AC}\left(\mathrm{O}_{3}\right)$

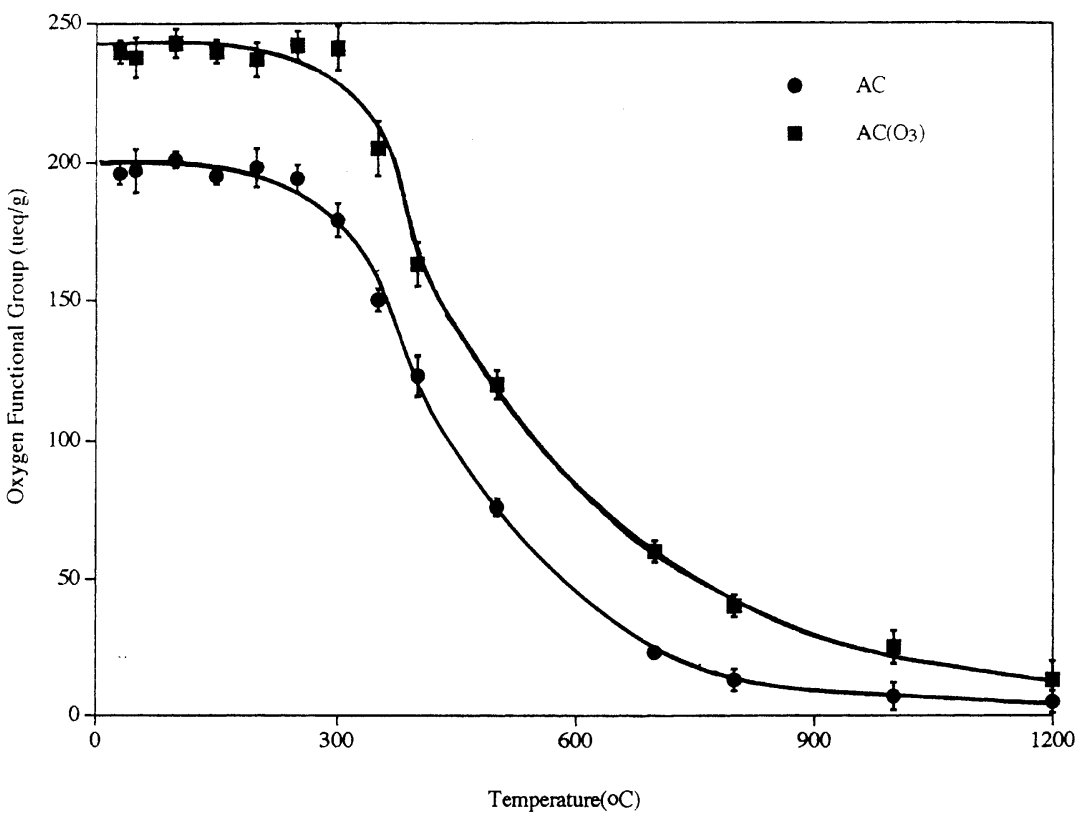

Fig. 4. Concentration of OFGs at various temperatures. 


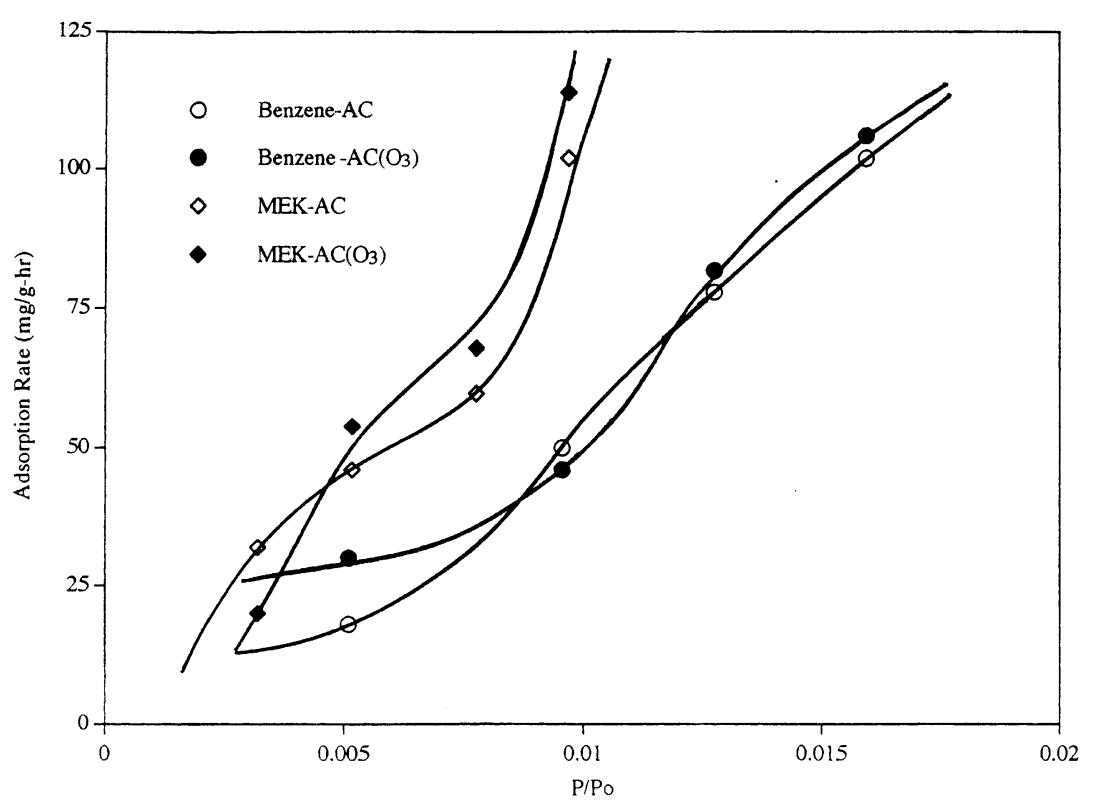

Fig. 5. AR of benzene and MEK on $\mathrm{AC}$ and $\mathrm{AC}\left(\mathrm{O}_{3}\right)$.

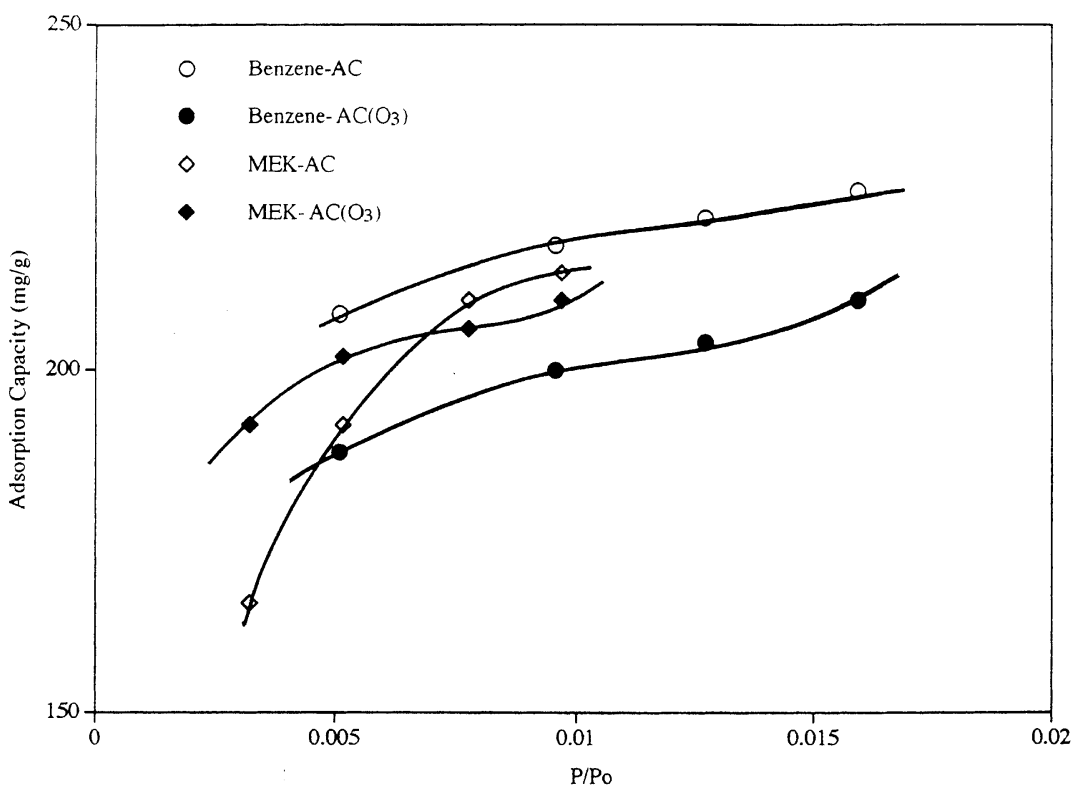

Fig. 6. Adsorption capacity of benzene and MEK on $\mathrm{AC}$ and $\mathrm{AC}\left(\mathrm{O}_{3}\right)$.

when the influent relative vapor pressure increases from 0.003 to 0.010 . The adsorption density of MEK by AC is greater than that on $\mathrm{AC}\left(\mathrm{O}_{3}\right)$ when the influent relative vapor pressure is greater than 0.008. Results indicate that capillary condensation (physical adsorption) is the predominant mechanism for VOC adsorption at high concentrations. At low VOC concentrations, however, chemisorption plays an important role in the adsorption process. MEK is a slightly polar adsorbate, therefore the MEK adsorption density on $\mathrm{AC}\left(\mathrm{O}_{3}\right)$ (a more polar surface) is greater than of AC. The benzene adsorption density of $\mathrm{AC}$ is greater than that of MEK due to greater affinity exhibited by evident of the greater adsorption energy of benzene $(34.4 \mathrm{~kJ} / \mathrm{mol})$ than as in 
MEK $(23.5 \mathrm{~kJ} / \mathrm{mol})$, as reported above (Chiang et al., 2002).

\subsection{Factorial analysis}

In order to evaluate the relationship among adsorption density, AR and various physical-chemical properties of the activated carbon, a statistical analysis of these parameters was conducted using the software, Statistical Analysis System (SAS). The data were inputs into the software program, which generate "factor loading". Table 4 shows results of the SAS analysis.

Results clearly indicated that all physical properties (variables), i.e., MA, BET surface area (BET), PD, and MV are closely related to each other as indicative of their corresponding high "factor loadings". For benzene adsorption, OFG is the sole important factor affecting both adsorption density $(Q)$ and AR.

OFG again becomes the sole important factor affecting the adsorption capacity of MEK (Group II). The AR of MEK is only affected by the MV.

\section{Conclusions}

Ozonation of activated carbon can increase the specific surface area and surface OFGs. Ozone reacts with the physical structure of the activated carbon enlarging the pore size and creates new pores. Increase in pore structure is seen at the micropore level. Increase in surface functional groups is seen mostly in hydroxyl and carboxyl groups. OFGs are stable between 30 and 250 ${ }^{\circ} \mathrm{C}$ and begin to decompose at $350{ }^{\circ} \mathrm{C}$. Results of factorial analysis indicate that physical characteristics of the adsorbent, e.g., BET specific surface areas, MAs and pore diameter are the major parameters for benzene and MEK adsorption.

\section{References}

Adamson, W.A., 1982. Physical and Chemistry of Surface. Wiley, New York.

Bansal, R.C., Dhami, T.L., Parkash, S., 1977. Surface characteristics and surface behaviour of polymer carbons. I. Associated oxygen and hydrogen. Carbon 15, 157-160.

Bansal, R.C., Vastola, F.J., Walker, P.L., 1970a. Studies on ultra-clean carbon surface. IV. Decomposition of carbonoxygen surface complex. Carbon 8, 443-448.

Bansal, R.C., Vastola, F.J., Walker, P.L., 1970b. Studies on ultra-clean carbon surface. II. Kinetics of chemisorption of oxygen on graphon. J. Colloid Sci. 32, 187-194.

Barrett, E.P., Joyner, L.S., Halenda, P.P., 1951. The determination of pore volume and area distributions in porous substances. I. Computations from nitrogen isotherm. J. Am. Chem. Soc. 73, 373-380.
Boehm, H.P., 1966. Chemical identification of surface groups. In: Eley, D.D., Pines, H., Weisz, P.B. (Eds.), Advances in Catalysis, vol. 16. Academic Press, New York, p. 179.

Brunauer, S., Emmett, H.P., Teller, E., 1938. Adsorption of gas in multimolecular layers. J. Am. Chem. Soc. 60, 309-319.

Chiang, H.L., Huang, C.P., Chiang, P.C., 2002. The adsorption of benzene and methylethylketone onto activated carbon: thermodynamic aspects. Chemosphere 46 (1), 143-152.

Deitz, V.R, Bitner, J.L., 1972. The reaction of ozone with adsorbent charcoals. Carbon 10, 145-154.

Deitz, V.R., Bitner, J.L., 1973. Interaction of ozone with adsorbent charcoals. Carbon 11, 339-401.

Donnet, J.B., Ehrburger, D., Voet, A., 1970a. Etude cinetique de l'oxydation d'un noir au four par l'ozone en milieu aqueux. Carbon 8, 697-705.

Donnet, J.B., Ehrburger, D., Voet, A., 1970b. Etude du mecanisme d'oxydation des noirs de carbone par l'ozone en milieu aqueux. Carbon 10, 737-746.

Donnet, J.B., 1982. Structure and reactivity of carbons: from carbon black to carbon composites. Carbon 20, 266-282.

Fabish, T.J., Schleifer, D.E., 1984. Surface chemistry and carbon black work function. Carbon 22, 19-38.

Hagiwan, S., Tsutsumi, K., Takahashi, H., 1978. Surface polarity of carbon blacks. Carbon 16, 89-93.

Hahn, C.S., Cho, H.S., Yang, H.S., 1981. Conversion of graphite into mellitic acid. Carbon 19, 225-229.

Harkins, W.D., Jura, G., 1944. Surfaces of solids XIII: a vapor adsorption method for the determination of the area of a solid without the assumption of a molecular area and the areas occupied by nitrogen and other molecules on the surface of a solid. J. Chem. Phys. 66, 1366-1373.

Hart, P.J., Vastola, F.J., Walker, P.L., 1967. Oxygen chemisorption on well leaned carbon surface. Carbon 5, 363-371.

Kinoshita, K., 1988. Carbon: Electrochemical and Physicochemical Properties. Wiley, New York.

Laine, N.R., Vastola, F.J., Walker, P.L., 1963. The importance of active surface area in the carbon-oxygen reaction. J. Phys. Chem. 67, 2030-2032.

Lussow, R.O., Vastola, F.J., Walker, P.L., 1967. Kinetics of oxygen interaction with graphon between 450 and $675{ }^{\circ} \mathrm{C}$. Carbon 5, 591-602.

Matsumura, Y., Hagiwara, S., Takahashi, H., 1976. Automatic potentiometric titration of surface acidity of carbon black. Carbon 14, 163-167.

Mattson, J.S., Mark Jr., H.B., 1971. Activated Carbon: Surface Chemistry and Adsorption from Solution. Marcel Dekker, New York.

Norwitr, G., Galan, M., 1967. Dissolution of carbon blacks by nitric acid. Carbon 5, 287-289.

Lippens, B.C., de Boer, J.H., 1965. Studies on pore system in catalysts $\mathrm{V}$ the $\mathrm{t}$ method. J. Catal. 4, 319-323.

Phillips, R., Vastola, J.F., Walker, P.L., 1970. Factors affecting the product ratio of the carbon-oxygen reaction. II. Reaction temperature. Carbon 8, 205-210.

Puri, B.R., 1970. In: Walker, P.L. (Ed.), Chemistry and Physics of Carbon. Marcel Dekker, New York, p. 191.

Puri, B.R., Bansal, R.C., 1964. Studies in surface chemistry of carbon blacks. II. Surface acidity in relation to chemisorbed oxygen. Carbon 1, 457-464.

Ruthven, D.M., 1984. Principles of Adsorption and Adsorption Process. Wiley, New York. 
Stern, A.C., 1977. Engineering Control of Air Pollution: Air Pollution-IV. Academic Press, New York.

Turkdogan, E.T., Vinter, J.V., 1969. Kinetics of oxidation of graphite and charcoal in carbon dioxide. Carbon 7, 101117.

Turkdogan, E.T., Vinter, J.V., 1970. Effect of carbon monoxide on the rate of oxidation of charcoal, graphite and coke in carbon dioxide. Carbon 8, 39-53.
Urano, K.S., Omori, S., Yamamoto, E., 1982. Prediction method for adsorption capacities of commercial activated carbon in removal of organic vapors. Environ. Sci. Technol. 12, 10-14. Walker, P.L., Janov, J., 1968. Hydrophilic oxygen complexes on activated carbon. J. Colloid Sci. 28, 449-458.

Zarifyanz, Y.A., Kisekv, V.F., Lezhnev, N.N., Nikitina, O.V., 1967. Interaction of graphite fresh surface with different gases and vapor. Carbon 5, 127-135. 